\title{
The Political Economy of Village Level Theocracies in the İlàjẹ Coastline, Southwest Nigeria
}

\author{
Babajide Ololajulo \\ University of Ibadan, Nigeria. \\ bo.ololajulo@ui.edu.ng, bo.ololajulo@gmail.com
}

\begin{abstract}
In 1947, a group of fishermen from the coastal area of İlàjẹ, Ondo State, Nigeria who were members of the Aládúrà, an independent Church movement in southwest of Nigeria, came together to establish a theocratic settlement, which they named Ayétòrò. A few years after, other theocratic settlements emerged in quick succession and by 1980 there were more than fifty such villages along the llàje coastline. The pertinent question is why this form of community organization is pervasive among the Illàje. The main argument of this article, following ethnographic data collected from four theocratic settlements, which are regarded as the core village theocracies, is that a flexible land tenure regime and a loose traditional political system, among other factors of environment and kinship structure, ensured easy access to land and served to authenticate the spiritual leadership claims of founders of theocratic settlements. The conclusion reflects on the future of theocratic settlements against the background of increasing modernization along the llàje coastline.
\end{abstract}

\section{Introduction}

In this article, I adopt a political economy approach in explaining the proliferation of a unique form of settlements, which Stanley Barrett has described 
as village theocracies, on the İlàje coastline of Ondo State, Nigeria. ${ }^{1}$ With the political economy approach, I am not just looking at the politico-economic interface but also the subsistence processes, including the dynamic interaction of man, environment, and social structure among other social and economic factors which anthropologists often adopt as frame of reference in their own limited usage of the political economy concept. I am much concerned with the unnoticed but yet powerful influences such factors constitute in the making and perpetuation of İlàjẹ theocratic settlements.

The literature on İlàjẹ theocratic settlements has been scanty although Ayétòrò, the earliest of such communities has been extensively studied. ${ }^{2}$ In the particular example of Ayétòrò, it was the communal form of organization and the rapid infrastructural and economic modernization achieved that attracted the attention of scholars. Little or no attention was given the social and cultural formations of the larger İlàje environment in which the community has evolved. Thus, J. D. Y. Peel in his review of Barrett's seminal work on Ayétòrò, The Rise and Fall of an African Utopia: A Wealthy Theocracy in Comparative Perspective, criticizes the author over the very thin account of the ethnography of the İlàje whom Peel suggests are different from the Yorùbá generally, both in cultural and social organization. ${ }^{3}$ Peel has gone a step further to argue that "in no other part of Yorùbá land has religious independency involved the establishment on this scale of 'theocratic' settlements to rival local communities". ${ }^{4}$ While one can simply explain the emergence of these settlements in terms of the Aládúrà doctrine of physical separation from non-members, it is also not too difficult to point out that Aládúrà aficionados in other Yorùbá towns did not establish new settlements but at best have carved out, within existing communities, separate spaces that are either called Orí-òkè (mountain) or Àgbàlá (courtyard). ${ }^{5}$

1. Stanley R. Barrett, Two Villages on Stilts: Family and Economic Change in Nigeria (New York: Chandler Publishing Company, 1974); idem, The Rise and Fall of an African Utopia: A Wealthy Theocracy in Comparative Perspective (Waterloo, Ontario: Wilfred Laurier University Press, 1977); idem, "Communalism, Capitalism and Stratification in an African Utopia," Journal of Asian and African Studies, 13.1-2 (1978): 112-29; idem, "From Communalism to Capitalism: Two Phases of Social Control in an African Utopia," Contemporary Crises, 3 (1979a): 269-289; idem, “The Politics of Defection from an African Utopia," Africa, 49 (1979b): 1-14.

2. Ibid.; Omafume Onoge, Aiyetoro, "The Successful Utopia: A Sociological Study of the Holy Apostles' Community in Nigeria," Ph.D. Thesis, Harvard University, 1969.

3. J.D.Y. Peel, "Review: The Rise and Fall of an African Utopia: A Wealthy Theocracy in Comparative Perspective by Stanley R. Barrett," Man, 14.1 (1979), 172-73.

4. Ibid., 173.

5. For extensive discussion on the Aladura, see Akin Omoyajowo, "The Aladura Churches in Nigeria since Independence," in E. Fashole-Luke, ed., Christianity in Africa (London: Rex Collins Ltd., 1978). 
Drawing motivation from Peel's observation about the peculiarity of theocratic settlements to the İlàjẹ area, this article attempts an explanation for the proliferation of "religious communities" that have since constituted a cultural feature of the İlàjẹ. I argue that environmental factors of concomitant political and economic proportions - rather than any notion of marked sociocultural differences between the İlàjẹ and other Yorùbá subgroups, as Peel suggests are behind the wave of independent religious settlements that developed along the İlàjẹ coastline starting from the late 1940s.

The article is divided into five sections. Following the introduction, I present a background on the İlàje people and their environment. This is followed by an ethnographic narrative of the modes of organizations in theocratic settlements. In this section I make reference to popularly held beliefs, but without identifying individual sources as this would often be impolitic. I then develop my arguments on the political and economic incentives that underlie the proliferation of theocratic settlements. The concluding section focuses on the future of the theocratic settlements.

\section{Ethnographic Setting}

İlàjẹland is situated along the coastline of Ondo State, Nigeria. The area consists of about one hundred small towns and villages that are organized into four subgroups - Àhérì, Ètikàn, Màhín, and Ugbò. All the subgroups speak the İlàjẹ dialect of Yorùbá language, and share similar sociocultural features. However, they lack a unifying tradition of origin although their different accounts all allude to a migration from Ilé-Ifè, the mythical home of the Yorùbá. In the pre- and post-independence era, two of the more prominent traditional authorities, the Àmàpetu, king of the Màhín, and the Olúgbò, king of the Ugbò, are engaged in an unrelenting battle of supremacy over which of the two groups first occupied the İlàjẹ coastline. ${ }^{6}$

Geopolitically, İlàjẹland occupies the entire İlàjẹ Local Government, one of the eighteen local government areas in Ondo State, although a few İlàje communities are also found in the adjoining Ogun State. The entire area came under colonial rule during the late nineteenth century by virtue of treaties which Àmàpetu and Olúgbò, the traditional rulers of Màhín and Ugbò kingdoms respectively, signed with the British imperial government, ceding their country and coastline to Britain. Prior to this time, the İlàjẹ are believed to have had contact with the Portuguese.

6. Joseph Seymour Eades, The Yoruba Today (Cambridge University Press, 1980). 
Early European contact from the sea did not, however, translate into access to social infrastructure: compared to the neighboring İjèbú and İkálè, the area remained backward in terms of education and other public utilities for many years. For instance, the first secondary school in İlàjẹ land was established in 1974. The first tarred road network to the İlàje coastline was initiated in 2004. The lateness in the establishment of schools, especially secondary schools, could be linked to the relatively slow penetration of the area by Christian missionaries. For instance, the Catholic mission had just a single outpost in Ėbúté-Ipáré while the Anglican maintained a minor presence in a few coastal villages such as İdíògbá and Ògógóró. Traditional practices like twin killing survived until the middle of the 20th century when many İlàjẹ became members of the Cherubim and Seraphim Church of Zion, founded by Yorùbá Christians from the Ijjèbú and Rémo areas. Important local breakaway movement of the Cherubim and Seraphim include the Holy Apostles Church.

In the coastal swamp of which most of İlàje consists, houses are built on stilts and a village is usually connected by a network of boardwalks, which are popularly known as foot bridges. During the rainy season, when the coastline is entirely flooded, it becomes possible to move from house to house in the dugout canoes which were, until the late 1960s, the main mode of transportation. Plank boats powered by very low capacity outboard engines and speed boats were introduced into the transportation system in the 1970s and 1980s respectively. In 1976, an extensive dredging of the inland water ways was commenced and by 1979 a major canal network running parallel the Ìlàje coastline from east to west had been completed. The canal network also extends to villages lying deep on the sea coast. Apart from the east-west canal, the water way from İdíògbá, on the coast, through the Màhín lagoon, up north to the creek that links to İgbókòdá in the west and İgbékèbó on the east, was also dredged. But by 2010, at least a quarter of the coastal area, especially the western flank, was accessible by road. A road project to the eastern part of the coastline was initiated in 2011 but not much progress has been made at the time of writing.

There are four similar and overlapping models the İlàjẹ settlements. Each settlement is defined by two broad typologies. The first is political authority, which could be traditional (Qjà İbílè) or theocratic (Qjà İgbàgbó), and the second, environment, which is either upland (Èbáhà and Èỳn òhà) or coastal (İgbèkun). The theocratic model, which is the focus of this article, is further divided into two categories - the Apostles Communities and the Zion Communities, both of which emerged from the Aládúrà Revival in İlàjẹ. While many Ojà İbílè are located a few miles away from the coastline, most village theocracies are based directly on the Atlantic coast. 


\section{Modes of organization in İlàjẹ theocratic settlements}

The first four Ojà İgbàgbó, also known as the core theocracies, were established in the late 1940s and early 1950s. The settlements emerged in quick succession: Ayétòrò, also known as the Holy Apostles Community, was established on the coastline in 1947, and Ugbónlá, a Zion settlement, ${ }^{7}$ was established south of the İlàjẹ town of Òde-Ugbò in 1948. The other two settlements, Oríòkè-İwàmímó (1950) and Zion- Pèpè (1951) were founded as a result of internal crises in the initial communities. While Oríòè-İwàmímó was an offshoot from Ayétòrò, Zion-Pèpè, on its part, was founded by breakaway members from Ugbónlá. According to some accounts, an Apostle community predating Ayétòrò was established in 1945 at a location close to the present settlement of Ayétòrò. According to this account, the pioneering community witnessed immediate decline and then eventual extinction after a number of the leaders left to found Ayétòrò. Stanley Barrett describes the founders of Ayétòrò as members of the Cherubim and Seraphim movement who were dissatisfied with the complacency of the church toward the local practice of twin killing. ${ }^{8}$

Apart from the four early settlements, later theocratic settlements include Rama Shiloh (Zion) and Òkè Sírì (Apostles), are located on the west of the İlàjẹ coastline. Several other Zion communities were successfully established by carving spaces for themselves within existing traditional communities by forming separate town quarters. This category of settlement includes the Zion communities in Òde-Màhín and İgbókòdá respectively, with the latter an important market town in İlàjẹ. Today, there are more than a fifty İlàjẹ villages that can be described as theocracies. Among these are Zion Ògógóró, Òkè Ėrí, Òkè Sílò, Okonlá, Ògo-Olúwáyo, Ayétuntun, Moférere, Òkè Éèwá and Holy Centre all Zion settlements on the Western fringe. To the east of the coastline are Hárámà and Ajégúnlè (Apostles), and İkórígho Zion. Most of these have been established in the post-independence years, but some many smaller ones lack the sophistication and structural organization of the early and large towns.

The emergence of village theocracies was initially resisted by the traditional authorities of the four cardinal İlàjẹ settlements. The case of Ayétòrò (Apostles) was particularly remarkable. Stanley Barrett describes how the Olúgbò, the traditional ruler at Òde-Ugbò, had in 1945 reported some of the Apostles, which included the founder of Ayétòrò, to the District Officer, accusing them of human sacrifice and other misdeeds. ${ }^{9}$ In addition, members of the new

7. The communities are often locally referred to as 'Zionist'. To avoid misunderstandings with the Jewish movement of Zionism I refer to them as 'Zion Communities'.

8. Barrett, The Rise and Fall of an African Utopia.

9. Ibid., 21. 
community were forbidden by the traditional rulers to use the natural canal that connected most of the riverine communities to the mainland where they could access markets for their products. The restriction was most probably effective because the canal passed through both Òde-Màhín and Òde-Ugbò. In order to circumvent the blockage, the Apostles were compelled to build a seven-mile canal, which bypassed the two antagonistic communities in the east to link up with the Màhín lagoon from where they could continue their journey to the mainland unhindered. Till date, this singular feat is a reference point when stories of the industry and resilience of the early Apostles are narrated.

İlàje theocratic settlements might be divided along the categories of Holy Apostles Communities and Zion Communities, but they all have similar systems of political organization in terms of the enormous power that resides in a theocratic leader who is commonly called Oba, which is the common Yoruba word for the ruler of a town. There are also structures such as the Oba-inCouncil (including the Oba and his chiefs), the Community Council, and the Trustees, which describe enlarged bodies of advisers that exercise political authority on behalf of the theocratic leader. The third noticeable line of authority is the Cherubim in the Zion Communities, which are also known as the Security in Apostle Communities. The differences in the ways theocratic communities are politically structured appear minor and may simply reflect an effort on the part of each community to establish an organizational framework which is different from the other community.

Founding leaders of most of the communities attained their positions by possessing spiritual qualities that surpassed those of other members of their groups. In most instances, it was each leader's unparalleled spiritual authority that galvanized his group and propelled them to seek an independent community outside of the various traditional settlements. In that wise, leadership seems naturally given, charismatic, and widely thought to be ordained by God. Similarly, the community councils established at the inception of new settlements were usually made up of close associates of the founders. Most members were spiritually gifted in their own right, but usually not to the same degree as the leaders. However, I also heard stories of certain personalities who possessed greater prophetic endowment than the founders but for one reason or the other were relegated to background roles.

It is not out of sheer lack of local equivalent vocabulary that leaders of theocratic settlements are called Oba. The word has strong traditional spiritual connotations but is also used to refer to Christian authority: Jesus might be called Oba Àikú, the Risen or Living King. The Oba of theocratic settlements are held in awe and worshipped like kings. Until recently, it was a common practice for community members who were by the road side to genuflect 
whenever they saw the leader approaching, and to remain in that position until after he had passed them.

The awe built around the Oba emanates from the prophetic power associated with them and is linked to myths about their unusual abilities to alter natural causality or to dispel doom and avert calamities. In Ugbónlá (Zion), for example, I heard a myth about a coconut tree which had never fruited but produced its first yield after Elisha Lénẹ Ògúnfèyími, the theocratic ruler and founder of the community, prophesied to it and commanded it to bear fruit within a year's time. In Oríòè-İwàmímó (Apostles), the founding leader, Ikúdèhìnbú, nicknamed Òkun Àjírí, "the pervasive ocean," was believed to have the power to invoke the sea's powers during an annual prophetic service held at the seaside. Such powers, which members of the community would attribute to no other person, were commonly cited as evidence of the divine authority of theocratic leaders.

In Ugbónlá (Zion), there is the position of a community chairman who in principle is next in rank to the Oba. He presides over the community council, which is composed of elders who, though they do not occupy a privileged position similar to the king's, command great respect from community members. I was, however, told that this arrangement of authority never really applies in the day to day running of the community. In the words of an informant, "when Lénẹ [Elisha Ilene, the founder of Ugbónlá] was alive the likes of Jéminé, Alàgbà and the rest [his close associates] were ahead of any community chairman." In a way, it appears the system of political authority is marked more by informality, which renders positioning in the political order more or less a function of the level of closeness a member can establish with the Oba. In the case of Ayétòrò (Apostles), the Oba-in-council exists as the authority next to the Oba alone. In the absence of the theocratic leader, the council superintends over the affairs of the community. The people commonly refer to the council as "constituted authority" and I think such nomenclature attests to the power, which council members can wield especially in the absence of the theocratic leader.

Meanwhile, even though the absolutism of a theocratic leader tends to diminish the position of council, it exists as a crucial link between the leader and the rest of the community. The council exercises administrative and judicial functions, and formulates policies that are announced as the decrees of the theocratic leaders. Community members, sometimes, might consider council's decisions to be self-serving and devoid of the approval of the theocratic leaders. Apart from some council members who earned their positions by virtue of the role they played in founding a community, other elders are appointed into the council by the theocratic leader. The council is the eyes and ears of the leader and most of its decisions can hardly be questioned because it is 
practically impossible for a common member to gain access to the theocratic leader. Armed with the stock response that, bàbá ti fò (the father/leader has said it); community councils assert their orders and extract from the ordinary members a level of respect thought to be deserved.

It is not uncommon for council members to be associated with accusations of financial impropriety and mismanagement. Suspicions of corrupt practices are accentuated by the fact that many members of council do not hold other offices or businesses. Since they administer the finances of the church, it does not take much of an effort for people to assume that the community treasury is their source of wealth. Such insinuations are apparently confirmed by the affluent lifestyles of council members, at least in relation to that of an average person in the community. Apart from allegations bordering on financial impropriety, council members are also regularly accused of making the most of their position as adjudicators on civil matters. In this way they may also draw suspicion or resentment away from the ruler.

Each village theocracy maintains an internal security outfit, which is composed of men of the church's Cherubim band in the case of Zion communities. (As mentioned above, in the Apostle communities, such outfits are simply known as Security.) The Cherubim or Security carry out the function of policing as well as implementing orders of the community council. They arrest members who flout the rules and regulations of the community and lay "cases" before the community council for appropriate disciplinary measures. Punishments such as flogging, suspension from church activities, and outright banishment are enforced by them. A member serving punishment is said to be under "Accuse," and is barred from wearing his or her official garment to the church. Moreover, such persons can be made to engage in manual labor during the entire duration of the sanction. The demeaning position of an "Accuse" is usually shared by members of his or her immediate household.

The essence of village theocracies is religious observance. As such, emphasis is placed on daily prayer sessions, fasting, Sunday service, prophecy and other religious performances, which define both the Christian faith and which were further emphasized in the Aládúrà Revival movement of which the Cherubim and Seraphim Church of Zion and the Holy Apostles Church were part. Although there are slight differences in the way Apostle communities and Zion communities conduct their affairs, the religious organization of theocratic settlements generally centers on hierarchy of authority in the church, its doctrinal practices, and the role of prophecy.

The church is organized along two broad divisions - the ordained ministers and the laity. The two categories are further formed along male and female lines. In Zion churches, for instance, the spiritual head who is also the head of the community is the highest ranked ordain minister and goes with the title of 
“The Most Reverend Apostle" or "King of Zion”. The latter designation appears a recent development originally adopted in Ugbónlá to establish a kind of distinctiveness for their leader as a reaction to proliferation of the title of "The Most Reverend Apostle" following an explosion in the number of village theocracies in the 1980s. Religious worship is conducted under strict observance of member's status and roles. Sitting arrangements in the church prioritize gender differentiation and set members apart in their respective ranks and bands. A number of the male ministers assists the spiritual leader to conduct services, while performing sundry duties like offering intercessory prayers, reading Bible lessons and making important announcements. In the absence of the leader, the most senior male minister oversees services.

Although their doctrines have evolved over the years, many continue to tally with the dogma of the Aládúrà movement. For instance, during their early years, prayer was seen as the antidote to all ailments and members were encouraged to visit prophets when their own abilities cannot ensure healings. Lately, however, most communities have sanctioned the use of Western medicine. Ayétòrò, particularly, led the revolution with the establishment of a community health centre that was run by trained dispensers and nurses. Apart from the state-run health centers that are now present in a few of these communities, there are drug stores operated by members. There is great emphasis on witches and spirits and their capacities to distort the life-world of man. Hence, regular revival and vigil services are organized by prophets to exorcize witches or spirits and to make witches confess their evil acts.

The communities maintain a strong stance against adultery and fornication, which appear the most common offences. A greater weight is accorded such misdemeanors in Apostle Communities where offenders are publicly flogged. I was told stories about students of the high school in Ayétòrò who, though they were not indigenes, received punishments from the community's Security for behavior bordering on fornication. I also heard of young men who were framed and publicly humiliated for daring to associate with young women that local leaders had their eyes on. Although I could not confirm these stories with any of the victims, they appear popular among people that schooled in Ayétòrò in the late 1970s and early 1980s.

However, in what may appear as double standard, prophets caught fornicating only received verbal reprimands, as they were believed to be under the spell of the devil. There was a uniform explanation of the fornicating prophet everywhere: "the devil was employing fornication and adultery to derail the path of 'God's servants' in order to render the entire community vulnerable." It thus became a pattern of social behavior for community members to sympathize with prophets guilty of fornication and to lament the spiritual retardation they experienced on that account. 
Polygyny is an acceptable practice in Ilaje theocratic communities, with the leaders setting precedence by marrying more than one wife. The practice is often justified with examples given of David, Solomon, and other personalities in the Old Testament who had many wives and concubines. I also heard a story of one of the very popular theocratic leaders who justified polygyny by making a mockery of the teachings of Apostle Paul on marriage. The leader, according to the story, claimed that Apostle Paul was against marriage because he, Paul, was a eunuch. Even when this opinion may be personal to the said leader, the polygynous orientation of İlàje theocratic settlements is perhaps indicative of a doctrinal peculiarity that sets both the Zion and Apostle Churches apart from many other Aládúrà churches.

Sunday sermons are mostly based on personal experiences of the leader in critical life matters. Sermon topics may range from the evil inherent in forming or associating with a conspirative group in the church, to such other mundane things as the manner in which the leader has been able to maintain peace among his numerous wives. During a sermon, the leader may allude to some past trips he has made to some big cities in Nigeria, mostly Lagos, Warri, and Port Harcourt, and other İlàjẹ fishing settlements in neighboring countries such as Cameroon and Gabon where branches of Zion churches are operated by migrant fishermen.

Such narrations serve to boost the image of the leader and set him over and above other members in terms of exposure and international connections, which to most members constitutes important social capital and validates the leader's exalted position. Apart from the practice of self-exultation, topics such as witchcraft, disobedience, and faith in God and His earthly representatives also receive regular treatment. Theocratic leaders will also admonish the laity to believe in the church leadership, which to them constitutes the basis upon which belief in God can be professed, asking "If you don't believe in the one leading the Sunday church service, how then can you claim that you believe in God?" In many of their sermons, the leaders appear to focus more on ensuring subjective power and preserving the settlement's hierarchical order.

It is also normal for sermons to be interrupted intermittently by songs. A song can be led by any member of the congregation who desires to either back the leader's message with a song or electrify the atmosphere of the church. This is described as "inviting the spirit". At times, the leader might stop a song from being rendered and would appeal to the aspiring singer for more time. During song rendition, a frenzy atmosphere prevails in the church and many prophets enter into the spirit realm. Calm only returns when, by the leader's signal, the song performance is brought to an end. People judge the success of a service by the length of time the "spirit came in." This, usually, depends on the intensity of songs coupled with the tempo of the accompanying drums. Apart from 
being able to engage in lively dance, members also anticipate the numerous visions that come with a spirited song performance.

The last aspect of theocratic settlements I will discuss in this article is the one that relates to community development. The early years of village theocracies were remarkable for the community development projects such as road construction, rural electrification, school buildings, community health centers, town halls, and communal entrepreneurship activities that were implemented. For instance, the first four secondary schools in the İlàje coastal area were established by the first four theocratic settlements. With such projects, communities like Ayétòrò, Ugbónlá, Oríòkè-İwàmímó and Zion-Pèpè were able to establish themselves as model communities that stood out from the cardinal settlements in terms of physical planning and public infrastructure.

Their development efforts were commended by some of the traditional authorities who had opposed the ideology and doctrines of the new settlements. Endorsement also came from the local colonial authority whom the theocratic villages had courted for support amidst opposition from the cardinal communities. In the particular case of Ayétòrò, the community achieved tremendous economic success as a theocracy and was described in the 1950s as a classic example of village level development in Nigeria. ${ }^{10}$

\section{Ìlàjẹ Theocratic Settlements: The Political Economy Perspective}

The main argument of this article is that in order to account for the proliferation of theocratic settlements on the İlàjẹ coastline, it is necessary to go a step beyond those explanations that situate the essence of theocratic settlements in religious fervor and the concomitant persecution of Aládúrà converts. ${ }^{11}$ Other factors, especially those rooted in the local political economy, provide the fertile ground for the establishment of new religious settlements.

Modernization on the İlàjẹ coastline seems to have occurred at a very slow pace compared to other parts of Yorùbáland. A vast portion of the coastline was not inhabited by 1900 and it may not be too farfetched to say that the largely swampy areas of which it consists were of little value until the late 1970s, when crude oil was discovered locally. Thus, the 1931 Census showed the entire İlàje population as made up of 4362 taxable males. ${ }^{12}$ The figure,

10. E. H. Duckworth, "A Visit to the Apostles Town of Ayetoro," Nigeria Magazine, 36 (1951).

11. Charlotte S. Neisser, "Community Development and Mass Education in British Nigeria," Economic Development and Cultural Change 3.4 (1955): 352-365.

12. National Archives Ibadan, Ilaje Intelligence Report, Ondo Prof. 1/1, File No.119, RJM Curwen, 1937. 
though likely underestimated as enumerators avoided difficult-to-access areas, reflects the low population density of İlàjeland and suggests an abundance of unoccupied land. Since farming was impracticable along the coastline, the only use to which the land could have been put was dwellings.

Although both the Àmàpetu and Olúgbò, the traditional rulers of ÒdeMàhín and Òde-Ugbò respectively, were said to have been in constant conflict over boundary matters in the pre-colonial years, the procedure for setting up a settlement in a portion of the coastline was not really well defined. Some of my informants who claimed their grandfathers established their present communities also reiterated that permission was not sought from any traditional authorities before the land was occupied. This could have applied to the theocratic settlements. Such claims also attest to the recent nature of many of the settlements. Oral accounts of the origin of coastal communities suggest that none of them existed before the late nineteenth century. However, there were suggestions that the earliest village theocracies were established on pieces of lands associated with the lineages of the respective founders and most of the initial members. In other words, the flexibility associated with land usage might have helped the cause of the religious communities. In the case of Ugbónlá, it was widely suggested that the founder of the community was an Ugbò prince, who could not have "begged" to establish his own community (meaning that he was able to do so without interference). These discussions on land use system will naturally take us to the second argument about theocratic settlements being frontier zones.

The tradition of origin of the four traditional settlements of the İlàje is often related in a manner that suggests timelessness in the people's occupation of the Ondo State coastline. It matters not to my effort here whether those stories are correct or not. However, the same may not be said of the coastal settlements that have attracted settlers from the older localities. The founding of these villages, which are usually fishing settlements, perhaps fits into what Igor Kopytoff describes as the "frontier process" - a series of issues pertaining to the movement of people out of their communities to form new settlements. ${ }^{13}$ For the theocratic settlements, therefore, their establishments follow an existing pattern of formation of new fishing settlements along the coast.

Without committing entirely to Marvin Harris's idea of infrastructural determinism, which aligns with some elements of the 'political economy' expla-

13. Igor Kopytoff, "The Internal African Frontier: The Making of African Political Culture," in I. Kopytoff, ed., The African Frontier: The Reproduction of Traditional African Societies (Bloomington and Indianapolis: Indiana University Press, 1987). 
nation, ${ }^{14}$ there is a way in which fishing opportunities can be incentives for people moving out of their kin groups to establish new communities. Although this will hardly explain the autonomous status of these settlements, it is likely to offer insights into the economic framework, upon which new polity were founded. Stanley Barrett, for instance, shows that Ayétòrò was able to generate huge income from ocean fishing. ${ }^{15} \mathrm{Up}$ to today the populations of theocratic settlements rely on fishing as a primary subsistence mode. Even Ugbónlá and Zion-Pèpè, which are located some few miles away from the coast, have their own share of the coastline where they access the ocean.

Fishing villages are distinguished by shared action and solidarity. ${ }^{16}$ This characteristic is indeed the underlying ideology of theocratic settlements. Could it then be that economic opportunities rather than religious zeal drove the formations of theocratic settlements? In which case, the communities are primarily fishing communities. While I am not inclined toward this kind of suggestion, it may nonetheless be emphasized that any explanation of migration might not be complete without mention of its economic rationality. The only problem with the theocratic settlement as fishing community explanation is the way in which lives in theocratic settlements divert from what Natalie Ross found concerning self-reliance and self-responsibility that are thought to characterize the lives of fishermen. ${ }^{17}$ While this holds true for other İlàje fishing communities that are not theocratic settlements, we see more control and intrusion into members' lives in the latter. The communal system of Ayétòrò at inception was an unusual case, and it is absent in theocratic settlements.

Beyond the fishing economy, there are political incentives to the formation of new communities. Already, we have talked about the privileged positions that leaders of theocratic settlements occupy. Such privileges offer a motivation for ambitious individuals to initiate a new community at the occurrence of conflict in the community of origin, whether theocratic or not: ambitions to lead are not in short supply. Stanley Barrett had made indirect reference to this when he described the founder of Oríokè-İwàmímó (Apostles), which he called Tálákà in his book, as a man thrown out of Olówó (Ayétòrò, also Apostles) for his political ambition. ${ }^{18}$

14. Marvin Harris, Cultural Materialism: The Struggle for a Science of Culture (New York: Random House, 1979).

15. Barrett, The Rise and Fall of an African Utopia.

16. Harold Fox, The Evolution of the Fishing Village: Landscape and Society along the South Devon Coast, 1086-1550 (Oxford: Leopard's Head Press, 2001).

17. Natalie Ross, "Understanding the Fishing 'Community': The Role of Communities of the Mind," Sociologia Ruralis, 55.3 (2015): 309-24.

18. Barrett, The Rise and Fall of an African Utopia, 15. 
The political ambition dimension is better understood when we consider the timeline of the first breakaways. For instance, Ayétòrò was founded in 1947 and Oríokè-İwàmímó, the breakaway settlement, was established in 1950. In a similar vein, Zion-Pèpè emerged out of Ugbónlá (both Zion) exactly four years after the settlement was founded. All of this assumes greater significance against the background that theocratic leaders do not only desire but are in actual fact accorded the status of Yorùbá Oba by their followers or 'subjects.' They wear beaded crowns, which they call adé ìgbàgbo (religious crown), and bear the horse tail - another symbol of royalty among the Yorùbá - during church services and at important ceremonies.

An informant who was concerned about what he has described as the "diminishing of the institution of Oba[ship]" by the theocratic leaders once told me that, "the ways these religious leaders comport themselves sometimes make me to feel that we are not Yorùbá." He may have been farfetched in his conclusion about his people's Yorùbá identity but such remarks also point to the traditional political culture that has been in place among the İlàjẹ. Although the Àmàpetu and the Olúgbò (two prominent traditional rulers of the İlàje) frown at the practice of religious leaders wearing beaded crowns, as is done in almost all other Yorùbá communities, there is no evidence that the religious leaders have been dissuaded from seeing their positions as similar to that of an Oba.

It is also important that we see the proliferation of theocratic settlements in terms of the promises of development they offer. The initial success of Ayétòrò served as an impetus for the replication of this form of community organization in many parts of the Ilaje coastline. Even though many of the communities do not follow the communal ideology of Ayétòrò, it is clear that they saw in a theocratic community a paradigm for economic development and infrastructural transformation. Ayétòrò demonstrated what collectivism can achieve outside of state interventionism, and there was no doubt that the state was indeed invisible in the İlàje area, perhaps until the 1980s. It is, therefore, not a coincidence that theocratic communities are better in physical planning and in community development initiatives than the coastal settlements organized along more traditional lines.

\section{Conclusion: The future of village theocracies}

Doubts were raised at inception of the earliest theocratic settlements about their ability to survive over a long period of time. It seems strange to most people in the cardinal settlements that communities could exist where religious leaders would exert control over members' personal beliefs and behav- 
ior. In the case of Ayétòrò, for instance, the traditional authorities at ÒdeMàhín and Òde-Ugbò were said to have predicted the imminent disintegration of the newly founded community within the first decade of its existence. To date, Ayétòrò people speak glowingly of their resilience amidst opposition from these communities and narrate how the community survived the predictions of premature disintegration that were made against it. A song of one of the most successful İlàjẹ highlife musician, Theophilus İwálòkun captures the mood that then surrounded the founding of the community.

Lójó tí wón kókó gun Oríòè Ayétòrò

Wón ní ká wò wón fún odún méta àti osù méfà

Bígbàgbó $\mathrm{w}^{\star} \mathrm{odb}^{\star} \mathrm{n}$ yó ti rí o

Bóyá wón á túnlè padà wá

Mà lộlé ò (2ce)

Kò sí òré bí Jésù láyé mó

The day Ayetoro was founded

Many said they should be watched for three and half years

To see what their faith would come to

Whether they would return to their former villages

Unto eternal home I focus (2ce)

There is no friend like Jesus in this world

In this other song, which qualifies as the community anthem, is contained Ayetoro's proclamation of accomplishment and invincibility.

Ayétòrò lékè (2ce)

Wò ó bí ó ti dára tó

Wò ó bí ó ti léwà tó

Bí èrò ayé kà mí gbógun

Sùgbón won kò lè se ohun tó wón nrò

Ayétòrò lékè

Ayetoro prevails (2ce)

Behold its goodness

Behold its beauty

Even when the world plots

Yet they can't execute their plans

Ayetoro prevails

The fervor that attends this song whenever it is rendered either during a church service or by pupils in the community primary school clearly underscores the belief the people yet have in their community. 
Interestingly, in spite of the early predictions of ultimate dissolution, Ayétòrò and other village theocracies survived and have continued to multiply. But as it may be expected of any human aggregation, nearly all the communities have experienced one form of crisis or the other. In the mid-1980s, Ayétòrò was almost devastated by a revolt led by a prominent youth, Sadiku, who attempted to set up a parallel church in the community. Similarly, at the death of the founding leaders, the stability of Ugbónlá, Zion-Pèpè, and Oríokèİwàmímó was threatened by succession crises forcing suggestions about the collapse of theocratic authority. However, despite a myriad of challenges, the İlàje village theocracies have managed to endure. The communities appear to possess the capacity for self-rejuvenation, such that even when they experience internal conflicts and appear close to the precipice, they hold on without losing a very important aspect of their being, which is ensuring that no parallel church operates in the community.

There is, however, no doubt that the most notable of the village theocracies have parted with some of the essential elements that make them model of rural developments in Ilaje land. The annual ordination and anniversary celebrations are still held but are devoid of the intense fervor once associated with them. In some of the communities there are splinter factions that stay away from religious worship and other activities initiated or led by the main factions. Moreover, the usual force behind the authorities of spiritual leaders has vanished: while many theocratic leaders determined voting choices in the past, more members now take independent decisions in elections without recourse to the theocratic leader.

Even on matters of internal security where the Cherubim once held sway, the Nigeria police has come in to forestall the breakdown of law and order, which has been very common in recent years. The traditional authorities at Màhín and Ugbò also preside over matters involving disputing parties from religious communities. I witnessed in 2011 a peace initiative of the Àmàpetu on the Oríòè-İwàmímó leadership crisis. At this moment the traditional authorities asserted their power over the theocratic communities, which they increasingly see as part and parcel of their respective kingdoms.

In recent years, not much has been done in terms of community development in most village theocracies, and especially in those that have gone through periods of crisis. Like other settlements, many theocratic settlements now depend solely on the state and intervention agencies to implement infrastructural projects. However, some aspects of communal work are still realized. This occurs mainly in the area of community sanitation, which is deemed necessary when an important guest such as the governor is making a visit or an annual festival is to be celebrated. However, it is observed that fewer members do participate in community labor and that fewer sanctions, if any, are 
imposed on uncooperative individuals. In a situation where the authority of some leaders is contested it would not be unexpected that a number of the local population would capitalize on the absence of community cohesion to evade certain responsibilities that were perhaps taken for granted in the past.

The opening up of İlàjẹland to influence from other parts of Yorùbáland and the level of educational attainments in many homes conflict with some of the conditions that helped entrench the village theocracies. For instance, few of the founders or earliest followers in theocratic communities had formal education. Instructions from the leaders then carried divine authority and dissensions were not contemplated. Some of my informants associated the crises which currently engulf the religious communities with modernity and blame the activities of educated members. Elites are accused of bringing "book sense" into purely spiritual matters and, by so, doing destroying the principles upon which the communities were founded. Certainly one of my informants, a university graduate, derogatorily referred to the Cherubim and Seraphim church as İjọ illiterate, meaning congregation or the church of illiterates.

As schools are now established in nearly all İlàjẹ towns and villages, including the religious communities, there is doubt whether an enlightened population will accept the overlord status of theocratic leaders in the same manner that obtained in the early period of the communities' existence. But equally, the lack of formal employment opportunities in the coastline has ensured that few highly educated elites are resident in riverine communities. Many young educated men and women quickly leave the villages for the towns to further their education or to seek employment upon completion of their secondary education.

But despite the potential transformative power of education, the religious communities seem not to lack in those who, at least in principle, enjoy being part of a theocratic fishing community. The unique spiritual experiences that can be had in both Holy Apostles and Cherubim and Seraphim churches are also highly valued by many İlàjẹ. Not a few of my informants said they preferred the "İlàjẹ churches" to the Pentecostal churches, which they called "Amen Amen" churches. The Pentecostal churches, they said, are devoid of the element of prophetic vision that is taken for granted in Holy Apostles and Cherubim and Seraphim churches. In the everyday lives of the people, prophets are found to be important and they are ascribed similar status as diviners in traditional communities.

Prophets forewarn others about the activities of witches and reveal visions of impending misfortune on members. Apart from the fact that a church service ends with the announcement of visions by the band of prophets, it is a common thing for the people to consult prophets in case of sickness, or when a journey is to be embarked upon. Justifying the visits to prophets, an infor- 
mant said that "it is only a tree that will stay glued to a point until it is hewn down", meaning that an intelligent being needs to have knowledge of the future in order to avoid misfortune. The local need for prophets may also be linked to the insecurity associated with fishing and trading. It is certainly the case that despite the success of the charismatic Pentecostal movements in many other areas of Yorùbáland, they have only enjoyed limited success along the İlàje coastline.

All the four classic village theocracies (Ayétòrò, Ugbónlá, Oríòkè-İwàmímó and Zion-Pèpè) have experienced crises of leadership succession. The problem of succession in the above examples emanated from the inability to reach a consensus on both the process of selection and the prospective "kings". Although succession crises are not uncommon in African indigenous churches, ${ }^{19}$ the uniqueness of the village theocracies lies in their relative size. In the case of Ugbónlá, it was rumored that the founding leader, on the point of death, made his wish known about the choice of a successor. The claim was disputed, and represented by a faction of the community as an imagination of a section of the Church's leadership that had been privileged to witness the founder's last hours. The community would later break into the camps of those who desired that the said wish be honored, and others who either were skeptical of such pronouncement or had insisted on what they considered the laid down procedure of succession. The leader that emerged after the protracted crisis was left with a fragmented community to govern.

As a whole, the extent of transformation which has taken place in the village theocracies is remarkable, and it invites further reflection on the mode of organization behind this unique feature of İlàjẹ settlement history. But beyond the very specific local incentives - low centralization and weak state presence, abundant land, lucrative fishing, and the opportunity for self-realization as a leader - there are similarities between the theocratic villages in İlàje and the numerous places, such as prayer mountains, established by other Aládúrà churches, and also with the Camps and Prayer Mountains of Nigerian Pentecostal churches. It would be interesting to explore these communities on the basis of their similarities rather than their differences.

19. Deji Ayegboyin and S. A. Ishola, African Indigenous Churches: An Historical Perspective (Lagos: Greater Heights Publications, 1997). 